\title{
EFEKTIVITAS PENGENDALIAN INTERNAL, ASIMETRI INFORMASI DAN IMPLEMENTASI GGG TERHADAP KECENDERUNGAN KECURANGAN AKUNTANSI PADA ORGANISASI PERANGKAT DAERAH KAB. INDRAGIRI HILIR
}

\author{
BADEWIN \\ Universitas Islam Indragiri Tembilahan \\ Email: badewin20@gmail.com
}

\begin{abstract}
This study empirically examines whether the effectiveness of internal control, information asymmetry and the implementation of the concept of good governance or good government governance (3G) on the tendency of accounting fraud (Fraud accounting) in Regional Apparatus Organizations (OPD) Indragiri Hilir Regency, Riau. The research was conducted at 12 offices in the Inhil Regency OPD. The sampling technique used is the census, a sample of 35 respondents. The type of data used was primary data. The data analysis model used is multiple linear regression analysis, with testing the quality of the data used is the validity test and reliability test. The results showed that partially the effectiveness of internal control variables, information asymmetry and the implementation of good governance had a good effect on the tendency of accounting fraud in OPD Indragiri Hilir Regency, Riau province. The result of the coefficient of determination test $\left(R^{2}\right)$ is $76 \%$ while the remaining $24 \%$ is explained by other variables.
\end{abstract}

Keywords : Internal Control, Information Asymmetry, Good Government Governance, Fraud accounting

\section{ABSTRAK}

Penelitian ini menguji secara empiris apakah efektivitas pengendalian internal, asimetri informasi dan implementasi konsep tata pemerintahan yang baik atau good government governance (3G) terhadap kecenderungan kecurangan akuntansi (Fraud accounting) pada Organisasi Perangkat Daerah (OPD) Kabupaten Indragiri Hilir Riau. Penelitian dilakukan pada 12 dinas yang ada di OPD Kabupaten Inhil. Teknik pengambilan sampel digunakan adalah sensus, sampel sebanyak 35 responden. Jenis data yang dipakai adalah data primer. Model analisis data digunakan adalah analisis regresi linear berganda, dengan pengujian kualitas data digunakan adalah uji validitas dan uji reabilitas.Hasil penelitian menunjukkan bahwa secara parsial variabel efektivitas pengendalian internal, asimeti informasi dan implementasi tata pemerintahan yang baik good governance governance berpengaruh baik terhadap kecenderungan kecurangan akuntansi pada OPD Kabupaten Indragiri Hilir provinsi Riau. Hasil uji koefisisen determinasi $\left(\mathrm{R}^{2}\right)$ sebesar $76 \%$ sedangkan sisanya $24 \%$ dijelaskan variabel lain.

Kata Kunci : Pengendalian Internal, Asimetri Informasi, Good Government Governance, Kecurangan Akuntansi

\section{PENDAHULUAN}

\subsection{Latar Belakang Masalah}

Organisasi Perangkat Daerah (OPD) adalah pelaksanaan fungsi eksekutif yang harus berkoordinasi agar penyelenggaraan pemerintah berjalan dengan baik. Berdasarkan Undang-undang nomor 23 tahun 2004 tentang Pemerintah Daerah dan peraturan pemerintah nomor 18 tahun 2016 tentang perangkat daerah disusun dan dibentuk kelembagaan OPD di lingkungan pemerintah kabupaten yang harus didorong lebih transparan, profesional dan efisien melalui pengambilan keputusan dan menjalankan tindakan dilandasi dengan nilai moral dan dipatuhinya peraturan perundang-undangan yang berlaku serta kesadaran akan adanya tanggungjawab sosial. Kasus kecurangan juga bisa terjadi di OPD karena masih terdapat kelemahan dalam kinerja pemerintah daerah serta penyusunan laporan keuangan di sebabkan adanya ketidakpatuhan terhadap peraturan perundang-undangan dalam pengelolaan laporan keuangan daerah ditemukan adanya penerimaan kembali dana pada Dinas yang tidak melalui mekanisme pembiayaan daerah.

Peraturan Undang-Undang No. 23 Tahun 2014 tentang Pemerintahan Daerah terdapat beberapa perubahan dan penyesuaian terhadap Organisasi Perangkat Daerah sebagai bentuk reformasi di tingkat daerah sehingga perubahan dalam penataan birokrasi menjadi suatu keharusan. Penataan Organisasi Perangkat Daerah ini muncul karena adanya ketidaksesuaian nomenklatur lembaga daerah dengan pusat (Pemerintah Pusat) yang selama ini sering mengakibatkan kesulitan proses penganggaran dan koordinasi yang berujung pada inefisiensi penyelenggaraan pemerintah di daerah. Penataan OPD ini dimana sebelumnya pemerintah sudah mengeluarkan Peraturan Pemerintah Nomor 41 Tahun 2007 tentang OPD yang berdasar pada UU No. 32 Tahun 2004. Sebagai pengganti PP No. 41/2007, pemerintah membuat Peraturan Pemerintah Nomor 18 Tahun 2016 Tentang Perangkat Daerah sebagai penyempurnaan dari PP Nomor 41 Tahun 2007 yang telah dicabut dan dinyatakan tidak berlaku lagi. Dibentuknya PP Nomor 18 Tahun 2016 ini atas pertimbangan yang ada dalam UU Nomor 23 Tahun 2004, yaitu dalam Pasal 232 ayat (1) dan adanya urusan pemerintahan yang

Badewin, Efektivitas Pengendalian Internal, Asimetri Informasi Dan Implementasi GGG Terhadap Kecenderungan Kecurangan Akuntansi Pada Organisasi Perangkat Daerah Kab. Indragiri Hilir 
diserahkan kepada daerah dan menjadi kewenangan daerah yang terdiri dari urusan wajib (berkaitan dengan pelayanan dasar dan non-pelayanan dasar) dan urusan pilihan (hanya dapat diselenggarakan oleh daerah yang memiliki potensi unggulan dan kekhasan daerah).

Efektivitas yang berarti berhasil atau sesuatu yang dilakukan berhasil dengan baik. Efektivitas organisasi adalah konsep tentang efektif dimana sebuah organisasi bertujuan untuk mengerjakan hal-hal yang benar, dimana sesuai dengan seharusnya diselesaikan sesuai dengan tujuan yang direncanakan. Namun ketika sesuatu yang telah direncanakan tidak berjalan sebagaimana mestinya atau terjadi kecurangan-kecurangan maka hal ini akan menghambat efektivitas organisasi. Untuk menghindari adanya tindakan-tindakan penyelewengan atau penyalahgunaan oleh pegawai dan menghasilkan laporan keuangan yang informatif dan akurat maka diperlukan pengendalian internal yang memadai khususnya pada asset kas. Asimetri informasi yaitu kondisi dimana salah satu pihak dari suatu transaksi memiliki informasi lebih banyak atau lebih baik dibandingkan pihak lain. Najahningrum (2013) menyatakan bahwa apabila tejadi kesenjangan informasi pengelola, maka akan membuka peluang bagi pihak pengelola dana untuk melakukan kecurangan. Asimetri informasi adalah suatu keadaan dimana antara pihak yang menyampaikan informasi dengan pihak yang menerima informasi terdapat ketidakselarasan didalam informasi tersebut. Selain efektivitas pengendalian inernal, asimetri informasi yang akan mempengaruhi kecenderungan kecurangan akuntansi terdapat faktor lainnya yaitu implementasi Good Government Governance (3G).

Implementasi $3 \mathrm{G}$ merupakan prasyarat bagi setiap pemerintah untuk memenuhi aspirasi masyarakat dalam mencapai tujuan dan good governance adalah sebagai pelayanan publik. Osborne dan Gaebler, (1992) berpendapat bahwa 3G memiliki kriteria yang berkemampuan untuk memacu kompetisi, akuntabilitas, responsip terhadap perubahan, transparan, berpegang pada aturan hukum, mendorong adanya partisipasi pengguna jasa, mementingkan kualitas, efektif dan efisien, mempertimbangkan rasa keadilan bagi seluruh pengguna jasa, dan terbangunnya suatu orientasi pada nilai-nilai. Implementasi good governance merupakan suatu gagasan dan nilai untuk mengatur pola hubungan antara pemerintah, dunia usaha swasta, dan masyarakat sehingga terjadi penyelenggaraan pemerintah yang bersih, demokratis dan efektif sesuai dengan cita-cita terbentuknya suatu masyarakat yang makmur. Hal ini mungkin saja terjadi pada lembaga pemerintah yaitu OPD, dimana jika lembaga pemerintah tidak memiliki manajemen yang baik maka akan mengakibatkan timbulnya kecurangan. menjelaskan kecurangan akuntansi sebagai salah saji yang menimbulkan kecurangan dalam pelaporan keuangan yaitu salah saji atau menghilangkan secara sengaja penyalahgunaan atau penggelapan (Willopo, 2006)

\subsection{Perumusan Masalah}

1. Apakah efektivitas pengendalian internal berpengaruh terhadap kecenderungan kecurangan akuntansi pada OPD Kabupaten Indrgiri Hilir?

2. Apakah asimetri informasi berpengaruh terhadap kecenderungan kecurangan akuntansi pada OPD Kabupaten Indrgiri Hilir?

3. Apakah implementasi good government governance berpengaruh terhadap kecenderungan kecurangan akuntansi pada OPDKabupaten Indrgiri Hilir?

4. Apakah efektivitas pengendalian internal, asimetri informasi dan implementasigood government governancesecara simultan berpengaruh terhadap kecenderungan kecurangan akuntansi pada OPD Kabupaten Indrgiri Hilir?

\section{TINJAUAN PUSTAKA}

\subsection{Efektivitas Pengendalian Internal}

Menurut Mulyadi (2002) pengendalian internal yang tertuang dalam PP No. 8 Tahun 2006 adalah suatu proses yang dipengaruhi oleh manajemen yang diciptakan untuk memberikan keyakinan yang memadai dalam pencapaian efektivitas, efesiensi, ketaatan terhadap peraturan perundang-indangan yang berlaku, dan keandalan penyajian laporan keuangan yang berdasarkan standar akuntansi yaitu PSAK yang dikeluarkan oleh Ikatan Akuntansi Indonesia (IAI).

Faktor-faktor yang menyebabkan pentingnya sistem pengendalian internal adalah sebagai berikut:

1. Perkembangan kegiatan dan skalanya menyebabkan komplesitas struktur, sistem dan prosedur organisasi semakin rumit.

2. Tanggung jawab bersama untuk melindungi asset organisasi, mencegah dan kesalahan-kesalahan serta kecurangan-kecurangan terletak pada manajemen sehingga manajemen harus mengatur sistem pengendalian intern yang sesuai untuk memenuhi tanggung jawab tersebut.

3. Pengawasan oleh dari satu orang (saling cek) merupakan cara yang tepat untuk menutup kecurangankecurangan yang bisa terjadi pada manusia

\subsection{Asimetri Informasi}

Zainal (2013), menyatakan bahwa asimetri informasi adalah situasi dimana terjadi ketidakselarasan informasi antara pihak yang memiliki atau menyediakan informasi dengan pihak yang membutuhkan atau menerima informasi. Jika terjadi kesenjangan informasi antara pihak pengguna dan pihak pengelola, maka akan membuka peluang bagi pihak pengelola dana untuk melakukan kecurangan

Badewin, Efektivitas Pengendalian Internal, Asimetri Informasi Dan Implementasi GGG Terhadap Kecenderungan Kecurangan Akuntansi Pada Organisasi Perangkat Daerah Kab. Indragiri Hilir 


\subsection{Implementasi Good Government Governance (3G)}

Menurut Unuted Nation Development Program (UNDP) bahasa 3G berasal dari dua kata yang diambil dari bahasa inggris yaitu good yang berarti baik dan governance yang berarti tata pemerintahan. Good governance didefinisikan sebagai suatu kesepakatan menyangkut pengaturan negara yang diciptakan bersama oleh pemerintahan, masyarakat dan swasta untuk mewujudkan kepemerintahan yang baik dan sehat secara umum.

\subsection{Kecenderungan Kecurangan Akuntansi}

Penggelapan ( fraud) dapat diartikan sebagai penyajian yang keliru atau usaha menyembunyikan kesalahan dengan maksud menipu pihak lain sehingga mengakibatkan kerugian. Menurut James A. Hall (2009) mendefinisikan kecurangan (fraud) sebagai suatu tindakan penipuan yang disengaja dilakukan yang menimbulkan kerugian pihak lain dan memberikan keuntungan bagi pelaku kecurangan dan atau kelompoknya.

\subsection{Kerangka Pemikiran}

Salah satu penyebab terjadinya kecurangan ialah kelalaian dan kesengajaan yang dilakukan seseorang. Ketika orang lain melihat tidak adanya halangan dalam jalan tersebut, maka seseorang akan cenderung untuk ikut melakukan kecurangan. Kecurangan akan dilakukan jika ada kesempatan dimana seseorangan harus memiliki akses terhadap aset atau unutuk meminimalisir peluang atau kesempatan seseorang untuk melakukan kecurangan maka diperlukan pengendalian internal yang efektif, menekan terjadinya asimetri informasi dan memasksimalkan implementasi good governance.

Disisi lain juga perlunya adanya efektivitas pengendalian internal. Menurut Ikatan Akuntansi Indonesia (IAI) efektivitas pengendalian internal merupakan sistem yang meliputi pemerintah untuk melindungi harta miliknya, memeriksa kecermatan dan keandaan data akuntansi serta meningkatkan efisiensi usaha. Menurut Unuted Nation Development Program (UNDP) pengertian good governance jika dikaitkan dengan tata kelola pemerintahan yang baik adalah suatu gagasan dan nilai untuk mengatur pola hubungan antara pemerintah, dunia usaha swasta, dan masyarakat sehingga terjadi penyelenggaraan pemerintah yang bersih, demokratis dan efektif sesuai dengan cita-cita terbentuknya suatu masyarakat yang makmur, sejahtera dan mandiri. Berdasarkan kerangka pemikiran diatas, maka dapat di gambarkan sebuah kerangka pemikiran sebagai berikut:

\section{Gambar 2.1}

Kerangka Pemikiran

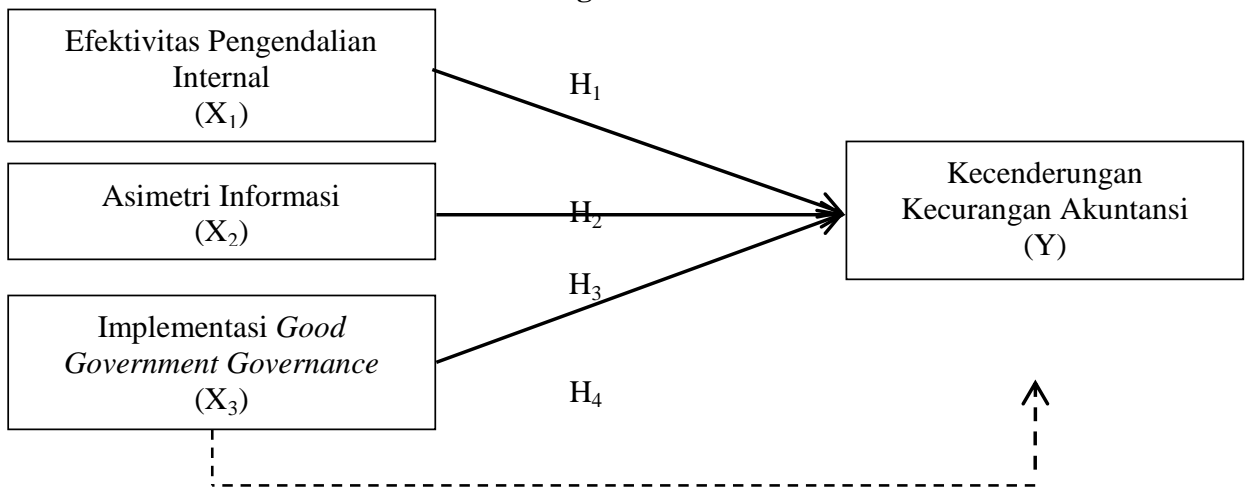

Variabel Independen

Variabel Dependen

Keterangan:

$$
\begin{aligned}
& \text { : Parsial } \\
& \text { : Simultan }
\end{aligned}
$$

2.5 Hipotesa

$\mathrm{H}_{1}$ : Efektivitas pengendalian internal berpengaruh terhadap kecenderungan kecurangan akuntansi pada OPD Kabupaten Indragiri Hilir.

$\mathrm{H}_{2}$ : Asimetri informasi berpengaruh terhadap kecenderungan kecurangan akuntansi pada OPD Kabupaten Indragiri Hilir.

$\mathrm{H}_{3}$ : Implementasi good governance governance berpengaruh terhadap kecenderungan kecurangan akuntansi pada OPD Kabupaten Indragiri Hilir.

$\mathrm{H}_{4}$ : Efektivitas pengendalian internal, asimetri informasi dan implementasi good government governance (secara simultan berpengaruh terhadap kecenderungan kecurangan akuntansi pada OPD Kabupaten Indragiri Hilir.

Badewin, Efektivitas Pengendalian Internal, Asimetri Informasi Dan Implementasi GGG Terhadap Kecenderungan Kecurangan Akuntansi Pada Organisasi Perangkat Daerah Kab. Indragiri Hilir 


\section{METODOLOGI PENELITIAN}

\subsection{Rancangan Penelitian}

Rancangan penelitian yang digunakan adalah hubungan kausal. Menurut Sugiyono (2013) hubungan kausal adalah hubungan yang bersifat sebab akibat. Pada penelitian ini terdapat empat variabel yaitu variabel independen (efektivitas pengendalian internal, asimetri informasi dan implementasi good governance) sedangkan variabel dependen (kecenderungan kecurangan akuntansi).

\subsection{Waktu dan Tempat Penelitian}

Waktu penelitian yang peneliti ambil dalam penelitian ini adalah selama tiga bulan dari bulan Mei sampai Juli 2019 dengan penyebaran kuesioner kepada para responden. Sedangkan penelitian ini dilakukan pada OPD (Satuan Kerja Perangkat Daerah) Kabupaten Indragiri Hilir.

\subsection{Populasi dan Sampel}

Populasi adalah wilayah generalisasi yang terdiri atas objek atau subjek yang mempunyai kualitas dan karakteristik tertentu yang ditetapkan oleh peneliti untuk dipelajari dan kemudian ditarik kesimpulan (Sugiyono, 2013). Populasi dalam penelitian ini adalah seluruh pegawai yang bekerja pada OPD Kabupaten Indragiri Hilir. Sampel adalah bagian dari jumlah atau karakteristik yang dimiliki oleh populasi (Sugiyono, 2013). Sampel dari penelitian ini adalah seluruh pegawai yang bekerja dibagian keuangan pada OPD Kabupaten Indragiri Hilir. Teknik pengambilan sampel adalah metode sensus dimana semua populasi dijadikan sampel.

\subsection{Prosedur Pengumpulan Data}

Data yang digunakan dalam penelitian ini adalah data primer. Menurut Sugiyono (2013) dan data primer adalah sumber yang tidak langsung memberikan data kepada pengumpul data dengan melalui kuisioner. Dengan mengirmkan kuesioner secara langsung pada OPD Kabupaten Indragiri Hilir, untuk setiap pegawai yang menjadi objek penelitian.Dengan harapan agar peneliti mendapatkan data yang maksimal. Sebelum menyebarkan kuesioner peneliti terlebih dahulu terjun ke tempat objek penelitian untuk mendapatkan izin penelitian.

\subsection{Teknik Analisa Data}

Metode yang digunakan dalam penelitian ini adalah teknik analisis regresi berganda. Tujuan dari analisa data adalah untuk mendapatkan informasi relevan yang terkandung dalam data tersebut dan menggunakan hasilnya untuk memecahkan suatu masalah (Ghozali, 2011). Analisis data dengan menggunakan program SPSS (Statistical Product And Service Solution) yang merupakan salah satu aplikasi komputer untuk menganalisis data statistik.

\section{HASIL PENELITIAN DAN PEMBAHASAN}

4.1 Hasil Penelitian

1. Statistik Deskriptif

Variabel dalam penelitin ini adalah asimetri informasi, implementasi good governance dan kecenderungan kecurangan akuntansi (fraud). Berikut adalah deskripsi statistik dari masing-masing variabel.

Tabel 4.1

Hasil Analisis Deskriftif

Descriptive Statistics

\begin{tabular}{|l|r|r|r|r|r|}
\hline & \multicolumn{1}{|c|}{ N } & \multicolumn{1}{|c|}{ Mean } & Std. Deviation & Minimum & Maximum \\
\hline Efektivitas pengendalian & 35 & 19.49 & 3.175 & 11 & 25 \\
internal & 35 & 24.03 & 2.443 & 21 & 30 \\
Asimetri informasi & 35 & 70.09 & 7.477 & 54 & 80 \\
Implementasi good governance & 35 & 50.94 & 7.604 & 39 & 62 \\
Kecenderungan kecurangan & & & \\
akuntansi & &
\end{tabular}

Sumber: Data olahan SPSS, 2019

Berdasarkan Tabel 4.1 diatas, statistik deskriftif dari variabel-variabel yang digunakan dalam penelitian ini menunnjukkan rata-rata variabel Efektivitas Pengendalian Internal 19.49 dengan std. deviasinya 3.175. Rata-rata variabel Asimetri Informasi 24.03 dengan std. deviasinya 2.443. Rata-rata Implementasi Good Governance 70.09 dengan std. deviasinya 7.477. Rata-rata Kecenderungan Kecurangan Akuntansi adalah 50.94 dengan std. deviasinya 7.604. Adapun hasil maximum untuk variabel Efektivitas Pengendalian Internal adalah 25 dengan minimum 11, maximum untuk variabel Asimetri Informasi adalah 30 dengan minimum 21, maximum untuk variabel Implementasi Good Governance adalah 80 dengan minimum 54, dan maximum untuk variabel Kecenderungan Kecurangan Akuntansi adalah 62 dengan minimum 39.

Badewin, Efektivitas Pengendalian Internal, Asimetri Informasi Dan Implementasi GGG Terhadap Kecenderungan Kecurangan Akuntansi Pada Organisasi Perangkat Daerah Kab. Indragiri Hilir 


\section{Hasil Uji Kualitas Data}

a. Uji Validitas

Penyebaran kuesioner khusus dalam uji validitas dan reliabilitas diambil langsung dari 35 responden dengan nilai $r_{\text {tabel }}$ sebesar 0,3338 Adapun hasil uji validitasmenggunakan program SPSS versi 20 untuk variabel Efektivitas Pengendalian Internal dapat dilihat dari tabel berikut ini:

\section{Tabel 4.2}

Hasil Uji Validitas Indikator Efektivitas Pengendalian Internal

\begin{tabular}{|l|c|c|c|}
\hline \multicolumn{1}{|c|}{ Indikator } & r Hitung & r Tabel & Keterangan \\
\hline Skor 1 & $0,652^{* *}$ & 0,3338 & Valid \\
\hline Skor 2 & $0,629^{* *}$ & 0,3338 & Valid \\
\hline Skor 3 & $0,657^{* *}$ & 0,3338 & Valid \\
\hline Skor 4 & $0,675^{* *}$ & 0,3338 & Valid \\
\hline Skor 5 & $0,802^{* *}$ & 0,3338 & Valid \\
\hline
\end{tabular}

Sumber: Data olahan SPSS, 2019

Berdasarkan tabel 4.2 diatas, pengujian validitas instrument penelitian (kuesioner) dengan 5 pertanyaan untuk variabel efektivitas pengendalian internalmendapatkan nilai $r_{\text {hitung }}>r_{\text {tabel }}$, yang mana $r_{\text {tabel }}$ dari 35 responden adalah 0,3338 sehingga keseluruhan instrumen penelitian tersebut dikatakan valid.

Tabel 4.3

Hasil Uji Validitas Asimetri Informasi

\begin{tabular}{|l|c|c|c|}
\hline Indikator & r Hitung & r Tabel & Keterangan \\
\hline Skor 1 & $0,542^{* *}$ & 0,3338 & Valid \\
\hline Skor 2 & $0,676^{* *}$ & 0,3338 & Valid \\
\hline Skor 3 & $0,563^{* *}$ & 0,3338 & Valid \\
\hline Skor 4 & $0,761^{* *}$ & 0,3338 & Valid \\
\hline Skor 5 & $0,550^{* *}$ & 0,3338 & Valid \\
\hline Skor 6 & $0,396^{* *}$ & 0,3338 & Valid \\
\hline
\end{tabular}

Sumber: Data olahan SPSS, 2019

Berdasarkan tabel 4.3 diatas, pengujian validitas instrumen penelitian (kuisioner) dengan 6 pertanyaan untuk variabel asimetri informasi mendapatkan nilai $r_{\text {hitung }}>r_{\text {tabel }}$, yang mana $r_{\text {tabel }}$ dari 35 responden adalah 0,3338 sehinga keseluruhan instrumen penelitian tersebut dikatakan valid.

Tabel 4.4

Hasil Uji Validitas Implementasi Good Goverment Governance

\begin{tabular}{|c|c|c|c|}
\hline Indikator & r Hitung & r Tabel & Keterangan \\
\hline Skor 1 & $0,690 * *$ & 0,3338 & Valid \\
\hline Skor 2 & $0,645 * *$ & 0,3338 & Valid \\
\hline Skor 3 & $0.641 * *$ & 0,3338 & Valid \\
\hline Skor 4 & $0,766 * *$ & 0,3338 & Valid \\
\hline Skor 5 & $0,682 * *$ & 0,3338 & Valid \\
\hline Skor 6 & $0,506 * *$ & 0,3338 & Valid \\
\hline Skor 7 & $0,470 * *$ & 0,3338 & Valid \\
\hline Skor 8 & $0,775 * *$ & 0,3338 & Valid \\
\hline Skor 9 & $0,401 * *$ & 0,3338 & Valid \\
\hline Skor 10 & $0,479 * *$ & 0,3338 & Valid \\
\hline Skor 11 & $0,372 * *$ & 0,3338 & Valid \\
\hline Skor 12 & $0,482 * *$ & 0,3338 & Valid \\
\hline Skor 13 & $0,528 * *$ & 0,3338 & Valid \\
\hline Skor 14 & $0,669 * *$ & 0,3338 & Valid \\
\hline Skor 15 & $0,679 * *$ & 0,3338 & Valid \\
\hline Skor 16 & $0,749 * *$ & 0,3338 & Valid \\
\hline Skor 17 & $0,614 * *$ & 0,3338 & Valid \\
\hline
\end{tabular}

Sumber: Data olahan SPSS, 2019

Berdasarkan tabel 4.4 diatas, pengujian validitas instrumen penelitian (kuisioner) dengan 17 pertanyaan untuk variabel implementasi good goverment governance mendapatkan nilai $r_{\text {hitung }}>r_{\text {tabel }}$, yang mana $r_{\text {tabel }}$ dari 35 responden adalah 0,3338 sehinga keseluruhan instrumen penelitian tersebut dikatakan valid.

Badewin, Efektivitas Pengendalian Internal, Asimetri Informasi Dan Implementasi GGG Terhadap Kecenderungan Kecurangan Akuntansi Pada Organisasi Perangkat Daerah Kab. Indragiri Hilir 
Tabel 4.5

Hasil Uji Validitas Kecenderungan Kecurangan Akuntansi

\begin{tabular}{|l|c|c|c|}
\hline \multicolumn{1}{|c|}{ Indikator } & r Hitung & r Tabel & Keterangan \\
\hline Skor 1 & $0,763^{* *}$ & 0,3338 & Valid \\
\hline Skor 2 & $0,490^{* *}$ & 0,3338 & Valid \\
\hline Skor 3 & $0.407^{* *}$ & 0,3338 & Valid \\
\hline Skor 4 & $0,486^{* *}$ & 0,3338 & Valid \\
\hline Skor 5 & $0,541^{* *}$ & 0,3338 & Valid \\
\hline Skor 6 & $0,645^{* *}$ & 0,3338 & Valid \\
\hline Skor 7 & $0,913^{* *}$ & 0,3338 & Valid \\
\hline Skor 8 & $0,536^{* *}$ & 0,3338 & Valid \\
\hline Skor 9 & $0,822^{* *}$ & 0,3338 & Valid \\
\hline Skor 10 & $0,461^{* *}$ & 0,3338 & Valid \\
\hline Skor 11 & $0,767^{* *}$ & 0,3338 & Valid \\
\hline Skor 12 & $0,869^{* *}$ & 0,3338 & Valid \\
\hline Skor 13 & $0,784^{* *}$ & 0,3338 & Valid \\
\hline
\end{tabular}

Sumber: Data olahan SPSS, 2019

Berdasarkan Tabel 4.7 diatas, pengujian validitas instrument penelitian (kuisioner) dengan 13 pertanyaan untuk variabel kecenderungan kecurangan akuntansimendapatkan nilai $r_{\text {hitung }}>r_{\text {tabel }}$, yang mana $\mathrm{r}_{\text {tabel }}$ dari 35 responden adalah 0,3338 sehingga keseluruhan instrumen penelitian tersebut dikatakan valid.

\section{b. Uji Reabilitas}

Instrumen memiliki tingkat reliabilitas yang tinggi jika nilai koefisien yang diperoleh $>0,70$ (Ghozali, 2011). Hasil analisis untuk uji reliabilitas terhadap instrumen pada empat variabel yang terdapat pada kuesioner dapat dilihat dibawah ini:

Tabel 4.6

\section{Hasil Uji Reliabilitas}

\begin{tabular}{|l|l|c|c|}
\hline No. & \multicolumn{1}{|c|}{ Variabel } & Alpha & Keterangan \\
\hline 1. & Efektivitas Pengendalian Internal & 0,755 & Reliabel \\
\hline 2. & Asimetri Informasi & 0,733 & Reliabel \\
\hline 3. & Implementasi Good Governance & 0,750 & Reliabel \\
\hline 4 & Kecenderungan Kecurangan Akuntansi & 0,761 & Reliabel \\
\hline
\end{tabular}

Sumber: Data olahan SPSS, 2019.

Hasil uji reliabilitas yang disajikan dalam tabel 4.6 diatas menunjukan bahwa nilai Alpha Cronbach hitung pada masing-masing variabel penelitian adalah lebih besar dari 0,70. Mengacu pada hasil tersebut maka dapat ditarik kesimpulan bahwa hasil pengukuran pada masing-masing variabel penelitian adalah reliabel atau konsisten.

\section{Hasil Uji Asumsi Klasik}

a. Uji Normalitas

Uji normalitas yang umum di pakai adalah P-P Plot dengan prinsip normalitas yang dapat dideteksi dengan melihat penyebaran data (titik) pada sumbu diagonal grafik atau dengan melihat histogram dari residualnya.Berikut hasil uji normalitas melalui program SPSS versi 20.

\section{Gambar 4.1}

\section{Uji Normalitas}

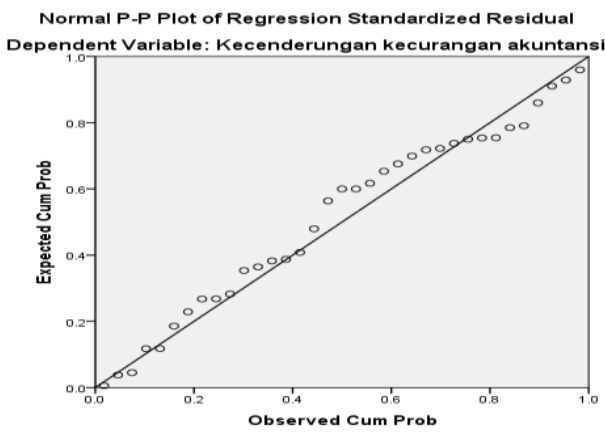

Sumber: Data olahan SPSS, 2019

Berdasarkan analisis kurva pada gambar 4.1 dapat dilihat bahwa data menyebar di sekitar diagram dan mengikuti model regresi sehingga dapat disimpulkan bahwa data yang diolah merupakan data yang berdistribusi normal sehingga uji normalitas terpenuhi. 


\section{Uji Heteroskedastisitas}

Uji Heteroskedastisitas bertujuan menguji apakah dalam model regresi terjadi ketidaksamaan varian dari residual satu pengamatan ke pengamatan yang lain. Jika varian dari residual satu pengamatan kepengamatan lain tetap, maka disebut homoskedastisitas dan jika berbeda disebut heteroskedastisitas. Untuk mendeteksi ada atau tidaknya heteroskedastisitas dapat dilakukan dengan melihat Grafik Plott (Scatter plot). Jika tidak terdapat pola yang jelas, seperti titik menyebar di atas dan dibawah angka 0 (nol) pada sumbu Y, maka tidak terdapat heteroskedastisitas. Adapun Hasil dari uji heteroskedastisitas dapat dilihat pada gambar berikut ini:

\section{Gambar 4.2}

\section{Uji Heteroskedastisitas}

$$
\text { Scatterplot }
$$

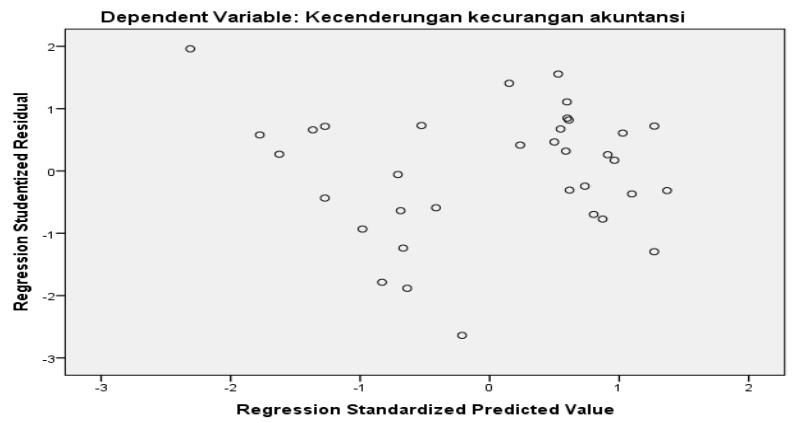

Sumber: Data olahan SPSS, 2019

Berdasarkan tabel 4.2 diatas dan hasil penelitian sebelumnya, maka model regresi penelitian ini tidak terjadi heteroskedastisitas. Hal ini dapat dilihat dari Grafik Plott diatas, dimana titik-titik tidak memperlihatkan pola yang jelas dan menyebar di atas dan di bawah angka nol pada sumbu Y.

\section{Uji Multikolinearitas}

Uji multikolonieritas bertujuan untuk menguji apakah model regresi ditemukan adanya korelasi antar variabel bebas (independen). Uji multikolinearitas dilakukan dengan menghitung nilai variance inflation factor (VIF) dari masing-masing variabel independen.Nilai yang umum dipakai untuk menunjukkan tidak adanya multikolinearitas adalah nilai VIF < 10.Berikut hasil uji multikolinearitas yaitu sebagai berikut:

Tabel 4.7

Uji Multikolinearitas

Coefficients $^{\mathrm{a}}$

\begin{tabular}{|c|c|c|c|c|c|c|c|}
\hline \multirow[t]{2}{*}{ Model } & \multicolumn{2}{|c|}{$\begin{array}{l}\text { Unstandardized } \\
\text { Coefficients } \\
\end{array}$} & \multirow{2}{*}{$\begin{array}{c}\begin{array}{c}\text { Standardized } \\
\text { Coefficients }\end{array} \\
\text { Beta }\end{array}$} & \multirow[t]{2}{*}{$\mathrm{t}$} & \multirow[t]{2}{*}{ Sig. } & \multicolumn{2}{|c|}{ Collinearity Statistics } \\
\hline & $\mathrm{B}$ & Std. Error & & & & Tolerance & VIF \\
\hline (Constant) & -32.387 & 8.857 & & -3.657 & .001 & & \\
\hline $\begin{array}{l}\text { Efektivitas pengendalian } \\
\text { internal }\end{array}$ & .641 & .206 & .267 & 3.109 & .004 & .970 & 1.031 \\
\hline Asimetri informasi & .810 & .276 & .260 & 2.940 & .006 & .916 & 1.092 \\
\hline $\begin{array}{l}\text { Implementasi good } \\
\text { governance }\end{array}$ & .733 & .090 & .721 & 8.152 & .000 & .918 & 1.089 \\
\hline
\end{tabular}

a. Dependent Variable: Kecenderungan kecurangan akuntansi

Sumber: Data olahan SPSS. 2019

Berdasarkan tabel 4.7 diatas terlihat bahwa nilai tolerance untuk variabel Efektivitas Pengendalian Internal sebesar 0,970, Asimetri Informasi sebesar 0,916 dan Implementasi Good Governance sebesar 0,918, dimana nilainya lebih dari 0,1 atau $10 \%$ dan nilai VIF untuk $\mathrm{X}_{1}$ sebesar $1,031, \mathrm{X}_{2}$ sebesar 1,092 dan $\mathrm{X}_{3}$ sebesar 1.089 dimana nilainya kecil dari 10 (sepuluh). Dengan demikian berarti dapat disimpulkan bahwa antar variabel bebas tidak mengandung multikolinearitas.

\section{Hasil Uji Hipotesa}

a. $\quad$ Uji Regresi Linear Berganda

Hipotesa dalam penelitian ini di uji dengan menggunakan metode regresi linear berganda, dengan alasan dalam penelitian ini menggunakan variabel independen lebih dari satu.Analisis regresi ini diolah dengan menggunakan SPSS versi 20. Adapun hasil olahan data tersebut dapat dilihat pada tabel berikut: 
Tabel 4.8

Uji Regresi Linier Berganda

Coefficients $^{\mathrm{a}}$

\begin{tabular}{|c|c|c|c|c|c|c|}
\hline \multirow{2}{*}{\multicolumn{2}{|c|}{ Model }} & \multicolumn{2}{|c|}{ Unstandardized Coefficients } & \multirow{2}{*}{$\begin{array}{c}\begin{array}{c}\text { Standardized } \\
\text { Coefficients }\end{array} \\
\text { Beta }\end{array}$} & \multirow[t]{2}{*}{$\mathrm{T}$} & \multirow[t]{2}{*}{ Sig. } \\
\hline & & $\mathrm{B}$ & Std. Error & & & \\
\hline \multirow{4}{*}{1} & (Constant) & -32.387 & 8.857 & & -3.657 & .001 \\
\hline & Efektivitas pengendalian internal & 641 & .206 & .267 & 3.109 & .004 \\
\hline & Asimetri informasi & .810 & .276 & .260 & 2.940 & .006 \\
\hline & Implementasi good governance & .733 & .090 & .721 & 8.152 & .000 \\
\hline
\end{tabular}

a. Dependent Variable: Kecenderungan kecurangan akuntansi

Sumber: Data olahan SPSS. 2019

Berdasarkan tabel 4.8 diatas, hubungan antara variabel independen dan variabel dependen dapat dirumuskan kedalam persamaan sebagai berikut:

$$
Y=-32,387+0,641 X_{1}+0,810 X_{2}+0,733 X_{3}+\varepsilon
$$

\section{b. Uji Parsial (Uji T)}

Uji t dilakukan untuk mengetahui besarnya pengaruh masing-masing variabel independen secara individual terhadap variabel dependen.Pengujian ini dilakukan dengan membandingkan nilai $t_{\text {hitung }}$ dengan $\mathrm{t}_{\text {tabel }}$ masing-masing variabel. Sesuai dengan hipotesa yang diajukan dalam penelitian ini, maka berdasarkan tabel 4.8 diatas secara terperinci dihasilkan pengujian sebagai berikut:

1. Hasil analisis terdapat nilai sig variabel efektifitas pengendalian internal yaitu 0,004 dimana nilai sig ini lebih besar dari nilai probabilitas 0,05 , atau nilai $0,004<0,05$, maka $\mathrm{H}_{1}$ diterima dan Ho ditolak. Variabel $X_{1}$ mempunyai $t_{\text {hitung }}$ yakni 3,109 dengan $t$ tabel 2,0345. Jadi $t_{\text {hitung }} X_{1} 3,109>t_{\text {tabel }} 2,0345$. Hal tersebut membuktikan bahwa variabel Efektivitas pengendalian internal merupakan variabel yang berpengaruh secara parsial terhadap kecenderungan kecurangan akuntansi pada OPD Kabupaten Indragiri Hilir.

2. Hasil analisis terdapat nilai sig variabel asimetri informasi yaitu 0,006 diman nilai sig ini lebih kecil dari nilai probabilitas 0,05 , atau nilai $0,006>0,05$, maka $\mathrm{H}_{2}$ diterima dan Ho ditolak. Variabel $\mathrm{X}_{2}$ mempunyai $t_{\text {hitung }}$ yakni 2,940 dengan $t$ tabel 2,0345 .Jadi $t_{\text {hitung }} X_{2} 2,9400>t_{\text {tabel }}$ 2,0345. Hal tersebut membuktikan bahwa variabel asimetri informasi merupakan variabel yang berpengaruh secara parsial terhadap kecenderungan kecurangan akuntansi pada SKPD Kabupaten Indragiri Hilir.

3. Hasil analisis terdapat nilai sig implementasi good government governance yaitu 0,000 dimana nilai sig ini lebih kecil dari nilai probabilitas 0,05 , atau nilai $0,000<0,05$, maka $\mathrm{H}_{2}$ diterima dan Ho ditolak. Variabel $\mathrm{X}_{3}$ mempunyai $\mathrm{t}_{\text {hitung }}$ yakni 8.152 dengan $\mathrm{t}_{\text {tabel }}$ 2,0345 .Jadi $\mathrm{t}_{\text {hitung }} \mathrm{X}_{3} 8.152>\mathrm{t}_{\text {tabel }}$ 2,0345.Hal tersebut membuktikan bahwa variabel implementasi good governance merupakan variabel yang berpengaruh secara parsial terhadap kecenderungan kecurangan akuntansi pada OPD Kabupaten Indragiri Hilir.

c. Uji Simultan (Uji F)

Uji F statistik digunakan untuk melihat apakah semua variabel bebas yang dimasukkan dalam model regresi mempunyai pengaruh secara bersama-sama terhadap variabel terikat.Hasil perhitungannya terangkum pada tabel berikut:

Tabel 4.9

Pengujian Hipotesa Secara Simultan ANOVA ${ }^{\mathrm{a}}$

\begin{tabular}{|ll|r|r|r|r|r|}
\hline Model & & Sum of Squares & \multicolumn{1}{|c|}{ Df } & Mean Square & F & Sig. \\
\hline \multirow{2}{*}{1} & Regression & 1528.316 & 3 & 509.439 & 36.092 & $.000^{\mathrm{b}}$ \\
& Residual & 437.569 & 31 & 14.115 & & \\
& Total & 1965.886 & 34 & & & \\
\hline
\end{tabular}

a. Dependent Variable: Kecenderungan kecurangan akuntansi

b. Predictors: (Constant), Implementasi good governance, Efektivitas pengendalian internal, Asimetri informasi

Sumber: Data olahan SPSS, 2019

Berdasarkan tabel 4.9 diatas, pengujian hipotesa mengenai variabel Desentralisasi dan Sistem Pengendalian Intern secara simultan pada tabel diatas diperoleh nilai $F_{\text {hitung }}$ yaitu 36,092 yang mana $F_{\text {tabel }}$ dari df1 3, df2 31 adalah 2,91 sehingga $F_{\text {hitung }}$ lebih besar dari $F_{\text {tabel }}, 36,092>2,91$. Pada tabel 4.9 diatas juga diperoleh nilai signifikannya sebesar 0,000. Dengan demikian dapat dibandingkan bahwa nilai signifikan pada tabel diatas $(0,000 \mathrm{~b})<0,05$ maka Ho ditolak dan Ha diterima, hal ini berarti variabel efektivitas pengendalian internal, asimetri informasi dan implementasi good governancesecara bersama-sama berpengaruh terhadap kecenderungan kecurangan akuntansi pada OPD Kabupaten Indragiri Hilir Riau

Badewin, Efektivitas Pengendalian Internal, Asimetri Informasi Dan Implementasi GGG Terhadap Kecenderungan Kecurangan Akuntansi Pada Organisasi Perangkat Daerah Kab. Indragiri Hilir 
d. Uji Koefisien Determinasi $\left(\mathrm{R}^{2}\right)$

Koefisien determinasi dilihat dari adjusted $R$ square yang artinya seberapa besar kontribusi variabel terikat. Uji koefisien determinasi yaitu mengukur seberapa jauh kemampuan model dalam menerangkan variasi variabel dependen. Adapun hasil dari uji dari koefisien determinasi dibawah ini:

Tabel 4.10

Hasil Koefesien Determinasi

Model Summary ${ }^{\mathrm{b}}$

\begin{tabular}{|l|r|r|r|r|}
\hline Model & \multicolumn{1}{|c|}{$\mathrm{R}$} & \multicolumn{1}{|c|}{ R Square } & Adjusted R Square & Std. Error of the Estimate \\
\hline 1 & $.882^{\mathrm{a}}$ & .777 & .756 & 3.757 \\
\hline
\end{tabular}
informasi

b. Dependent Variable: Kecenderungan kecurangan akuntansi

Sumber: Data olahan SPSS, 2019

Pada tabel 4.10 diatas menunjukan bahwa nilai adjusted $\mathrm{R}^{2}$ sebesar 0,756 hal ini berarti $76 \%$ variabel Kecenderungan kecurangan akuntansi dipengaruhi oleh tiga variabel penjelas yaitu Efektivitas Pengendalian Internal, Asimetri Informasi dan Implementasi Good Governance. Sisanya 24\% dipengaruhi oleh variabel lain yang tidak disetarakan dalam variabel penelitian ini.

\subsection{Pembahasan}

1. Pengaruh Efektivitas Pengendalian Internal Terhadap Kecenderungan Kecurangan Akuntansi

Variabel Efektivitas pengendalian internal memiliki pengaruh secara parsial terhadap kecenderungan kecurangan akuntansi pada Satuan Kerja Perangkat Daerah Kabupaten Indragiri Hilir. Dimana dapat dilihat dari nilai $t_{\text {hitunge }}$ efektivitas pengendalian internalsebesar 3,109sedangkan $t_{\text {tabel }}$ sebesar 2,0345sehingga $t_{\text {hitung }}>t_{\text {tabel }}$ dengan signifikan untuk variabel Efektivitas pengendalian internal lebih kecil dari pada nilai probabilitas 0.05 atau nilai $0,000<0,05$, maka $\mathrm{H}_{1}$ diterima dan Ho ditolak. Hal tersebut membuktikan bahwa variabel efektivitas pengendalian internal merupakan variabel yang berpengaruh secara parsial terhadap kecenderungan kecurangan akuntansi pada Satuan Kerja Perangkat Daerah Kabupaten Indragiri Hilir.

Hasil penelitian ini menunjukkan bahwa adanya efektivitas pengendalian internal yang dilakukan dalam Satuan Kerja Perangkat Daerah guna untuk melindungi harta milik instansi, memeriksa kecermatan dan keandalan data akuntansi serta meningkatkan efesiensi kinerja dengan cara seperti melakukan kontrol, pengawasan pekerjaan, pemantauan, komunikasi dan lain sebagainya sehingga hal ini dapat menghindari kesalahan-kesalahan atau pun kecurang-kecurangan yang terjadi atau bahkan penyelewengan dan sebagainya. Dimana ketika OPD menerapkan efektivitas pengendalian internal yang baik ketika melaksanakan pekerjaan maka hal ini akan membuat suatu pekerjaan itu dapat berjalan sesuai dengan prosedur yang telah direncanakan oleh Satuan Kerja Perangkat Daerah sehingga akan tercapai tujuan yang ingin diraih.Hasil ini mendukung teori yang diteliti oleh Saftarini, dkk (2015) yang menyatakan bahwa ada pengaruh antara variabel independen (efektivitas pengendalian internal) dengan variabel dependen (kecenderungan kecurangan akuntansi) bagian akuntansi dan keuangan pada OPD Kabupaten Bangli.

\section{Pengaruh Asimetri Informasi Terhadap Kecenderungan Kecurangan Akuntansi}

Variabel asimetri informasi memiliki pengaruh secara parsial terhadap kecenderungan kecurangan akuntansi pada OPD Kabupaten Indragiri Hilir. Dimana dapat dilihat dari nilai $t_{\text {hitungasimetri informasi }}$ sebesar 2,940 sedangkan $t_{\text {tabel }}$ sebesar 2,0345 sehingga $t_{\text {hitung }}>t_{\text {tabel }}$ dengan signifikan untuk variabel asimetri informasilebih kecil dari pada nilai probabilitas 0.05 , atau nilai $0,006<0,05$ maka $\mathrm{H}_{2}$ ditolak dan Ho diterima. Hal tersebut membuktikan bahwa variabel asimetri informasi merupakan variabel yang berpengaruh secara parsial terhadap Kecenderungan kecurangan akuntansi pada OPD Kabupaten Indragiri Hilir.

Hasil penelitian ini menunjukkan bahwa dengan adanya asimetri informasi maka kita bias mendapatkan sebuah informasi tentang terjadinya ketidakselarasan pada laporan akuntansi yang menyebabkan penyelewengan karna kurangnya informasi dari luar dan pihak lain dalam OPD. Asimetri informasi merupakan situasi dimana terjadi ketidakselarasan informasi antara pihak yang memiliki atau menyediakan informasi dengan pihak yang membutuhkan atau yang menerima informasi bila terjadinya kesenjangan informasi antara pihak pengguna dan pihak pengelola, maka akan membuka peluang bagi pihak pengelola dana untuk melakukan kecurangan.

Sejalan dengan hasil penelitian Aranta, dkk (2013), yang menyatakan bahwa variabel independen (asimetri informasi) berpengaruh signifikan terhadap variabel dependen (kecenderungan kecurangan akuntansi) pada Pemerintah Kota Sawahlunto. Setiap informasi yang berkaitan dengan pemerintah seharusnya disampaikan kepada para staf dengan merata sesuai dengan bidangnya masing-masing. Pemberian informasi secara merata kepada para staf sesuai dengan bidang masing-masing, akan menumbuhkan rasa tanggung jawab pada para staf.

Badewin, Efektivitas Pengendalian Internal, Asimetri Informasi Dan Implementasi GGG Terhadap Kecenderungan Kecurangan Akuntansi Pada Organisasi Perangkat Daerah Kab. Indragiri Hilir 


\section{Pengaruh Implementasi Good Governance Terhadap Kecenderungan Kecurangan Akuntansi}

Variabel implementasi good governance memiliki pengaruh secara parsial terhadap kecenderungan kecurangan akuntansi pada OPD Kabupaten Indragiri Hilir. Dimana dapat dilihat dari nilai $t_{\text {hitung }}$ implementasi good governancesebesar 8,152 sedangkan $t_{\text {tabel }}$ sebesar 2,0345 sehingga $t_{\text {hitung }}>t_{\text {tabel }}$ dengan signifikan untuk variabel implementasi good governancelebih kecil dari pada nilai probabilitas 0.05 , atau nilai 0,000< 0,05 maka $\mathrm{H}_{3}$ diterima dan Ho ditolak. Hal tersebut membuktikan bahwa variabel implementasi good governance merupakan variabel yang berpengaruh secara parsial terhadap Kecenderungan kecurangan akuntansi pada OPD Kabupaten Indragiri Hilir.

Hal ini menunjukkan bahwa dengan adanya peraturan di setiap OPD khususnya di Kabupaten Indragiri Hilir, maka akan mencegah terjadinya ketidakselarasan yang dapat merugikan pihak tertentu, implementasi good governance juga sangat penting untuk diterapkan di setiap OPD. Implementasi good governance merupakan suatu gagasan dan nilai untuk mengatur pola hubungan antara pemerintah, dunia usaha swasta dan masyarakat sehingga terjadi penyelenggaraan pemerintah yang bersih, demokratis dan efektif sesuai dengan cita-cita terbentuknya masyarakat yang makmur, sejahtera dan mandiri.

Hasil penelitian ini sejalan dengan penelitian Saputra, dkk (2015) menyatakan bahwa variabel independen (implementasi good governance) berpengaruh yang signifikan terhadap variabel dependen (kecenderungan kecurangan akuntansi) pada LPD di Kabupaten Buleleng bagian Timur. Dengan adanya tata kelola pemerintahan yang baik (Implementasi good governance) adalah partisipasi masyarakat, tegaknya supermasi hokum, transparansi, berkeadilan, daya tanggap, berorientasi consensus, efektivitas dan efisiensi, akuntabilitas, visi strategis dan saling keterkaitan.

\section{Pengaruh Efektivitas Pengendalian Internal, Asimetri Informasi dan Implementasi Good Governance Terhadap Kecenderungan Kecurangan Akuntansi}

Variabel independen yaitu efektivitas pengendalian internal, asimetri informasi dan implementasi good governance dan secara simultan memiliki pengaruh terhadap variabel dependen kecenderungan kecurangan akuntansi pada Satuan Kerja Perangkat Daerah Kabupaten Indragiri Hilir. Hasil penelitian menunjukkan bahwanilai $F_{\text {hitung }}$ yaitu 36,092 yang mana $F_{\text {tabel }}$ dari df1 3, df2 31 adalah 2,91 sehingga $F_{\text {hitung }}$ lebih besar dari $\mathrm{F}_{\text {tabel }}, 36,092>2,91$. Dan diperoleh nilai signifikannya sebesar 0,000. Dengan demikian dapat dibandingkan bahwa nilai signifikan pada tabel diatas $(0,000 \mathrm{a})<0,05$ maka Ho ditolak dan Ha diterima, hal ini berarti variabel Efektivitas Pengendalian Internal, Asimetri Informasi Dan Implementasi Good Governance secara bersama-sama berpengaruh terhadap Kecenderungan Kecurangan Akuntansi pada Organisasi Perangkat Daerah (OPD)Kanbupaten Indragiri Hilir.

Dengan adanya efektivitas pengendalian internal, asimetri informasi dan implementasi good governance yang dilakukan dalamsatuan kerja perangkat daerah dapat mengurangi terjadinya kecurangan akuntansi.Di satu sisi satuan kerja perangkat daerah lebih mudah dalam pengambilan keputusan yang tepat dalam pembuatan rencana strategi untuk meraih tujuan satuan kerja perangkat daerah, karena setiap divisi manajemen lebih mengetahui keadaaan di ruang lingkupnya sehingga ketika mengambil keputusan secara independen. Selain itu juga dengan adanya efektivitas pengendalian internal maka satuan kerja perangkat daerahakan bisa mengontrol jalannya strategi atau rencana yang telah ditetapkan melalui pengendalian internal sehingga hal ini dapat menghindari kesalahan-kesalahan yang terjadi dan tujuan yang akan diraih satuan kerja perangkat daerah pun akan mudah untuk dicapai.

Hasil penelitian ini sejalan dengan penelitian Sari, dkk (2015), yang menunjukkan bahwa ada pengaruh yang signifikan antara variabel independen yaitu efektivitas pengendalian internal, asimetri informasi dan implementasi good governance terhadap variabel dependen kecenderungan kecurangan akuntansi Pada Satuan Kerja Perangkat Daerah di Kabupaten Tabanam. Dengan adanya efektivitas pengendalian internal, asimetri informasi dan implementasi good governance yang diterapkan pada OPD di Kabupaten Indragiri Hilir, maka hal ini akanmengurangi kecurangan akuntansi dengan cara mengambil keputusan yang tepat agar tujuan yang laksanakan dapat berjalan sesuai yang telah direncanakan.

\section{KESIMPULAN DAN SARAN}

Adapun kesimpulan dalam penelitian berdasarkan hasil penelitian yang telah dibaha maka

1. Variabel efektivitas pengendalian internal merupakan variabel yang berpengaruh secara parsial terhadap kecenderungan kecurangan akuntansi pada Satuan Organisasi Perangkat Daerah (OPD) Kabupaten Indragiri Hilir Riau

2. Variabel asimetri informasi variabel yang berpengaruh secara parsial terhadap kecenderungan kecurangan akuntansi pada Organisasi Perangkat Daerah (OPD) Kabupaten Indragiri Hilir Riau

3. Variabel implementasi good governancemerupakan variabel yang berpengaruh secara parsial terhadap kecenderungan kecurangan akuntansi pada OrganisasiPerangkat Daerah(OPD) Kabupaten Indragiri Hilir Riau

4. Variabel independen yaitu efektivitas pengendalian internal, asimetri informasi dan implementasi good governance memiliki pengaruh secara simultan terhadap variabel dependen yaitu kecenderungan kecurangan akuntansi pada Satuan Kerja Perangkat Organisasi Kabupaten Indragiri Hilir. Nilai signifikan sebesar 0,000 . Variabel efektivitas pengendalian internal, asimetri informasi dan 
implementasi good governance secarabersama-sama berpengaruh terhadap kecenderungan kecurangan akuntansi pada Organisasi Perangkat Daerah (OPD) Kabupaten Indragiri Hilir.Dan hasil uji koefisien determinansi $\left(\mathrm{R}^{2}\right)$ diperoleh dari nilai (Adjusted $\mathrm{R}$ Square) sebesar 0,756 hal ini berarti $76 \%$ variabel kecenderungan kecurangan akuntansi dipengaruhi oleh tiga variabel penjelas yaitu efektivitas pengendalian internal, asimetri informasi dan implementasi good governance. Sisanya $24 \%$ dipengaruhi oleh variabel lain yang tidak disetarakan dalam variabel penelitian ini.

\section{DAFTAR PUSTAKA}

Aranta, Zulia, Petra. 2013. Pengaruh Moralitas Aparat dan Asimetri Informasi Terhadap Kecenderungan Kecurangan Akuntansi (Studi Empiris Pemerintah Kota Sawahlunto). Universitas Negeri Padang, Padang.

Ghazali, Imam 2011. Aplikasi Analisis Multivariate dengan Program SPSS 20. Badan penerbit Universitas Diponegoro: Semarang.

Hall, James A. 2009. Sistem Informasi Akuntansi, Buku 1 Edisi 4. Salemba Empat. Jakarta.

Mulyadi. 2002. Sistem Akuntansi. Edisi 3, Cetakan 3. Salemba Empat. Jakarta

Najahningrum, Anik Fatun. 2013. Faktor-Faktor yang mempengaruhi Kecenderungan Kecurangan (Fraud): Persepsi Pegawai Dinas Provinsi DIY. Universitas Negeri Semarang, Semarang.

Osborne dan Gaebler. 1992. Good Governance. Kompetisi, akuntabilitas, responsip terhadap perubahan, transparan dan aturan hukum.

Saftarini, Rita, Putu, dkk. 2015. Pengaruh Efektivitas Pengendalian Internal, Asimetri Informasi dan Implementasi Good Governance Terhadap Kecenderungan Kecurangan (Fraud) Akuntansi (Studi Empiris Pada Skpd Di Kabupaten Bangli). Jurnal SI Ak Pendidikan Ganesha. Vol. 3, No. 1. Padang.

Sari, Purnama; Putu, dkk. 2015. Pengaruh Efektifitas Sistem Pengendalian Internal, Ketaatan Aturan Akuntansi, Persepsi Kesesuaian Kompensasi dan Implementasi Good Governance Terhadap Kecenderungan Fraud (Studi Empiris Pada Skpd Di Kabupaten Tabanan). Jurnal SI Ak Pendidikan Ganesha. Vol. 3, No. 1. Indonesia.

Saputra, Krisna dan Gede, dkk. 2015. Pengaruh Pengendalian Intern Kas, Implementasi Good Governance dan Moralitas Individu Terhadap Kecurangan (Fraud) (Studi Empiris Pada LPD Di Kabupaten Buleleng Bagian Timur).Jurnal SI Ak Pendidikan Ganesha. Vol. 3, No. 1. Padang.

Sugiyono. 2013. Metode Penelitian Pendidikan Pendekatan Kuantitatif,. Kualitatif, dan R\&D. Alfabeta: Bandung

Willopo.2006. Analisis Faktor-Faktor YangBerpengaruh Terhadap Kecenderungan Kecurangan Akuntansi Studi Pada Perusahaan Publik dan Perusahaan Badan Usaha Milik Negara. SNA IX : Padang

Zainal, dkk. 2013. Pengaruh Efektivitas Pengendalian Intern, Asimetri Informasi dan Kesesuaian Kompensasi Terhadap Kecenderungan Kecurangan Akuntansi (Fraud. (Studi Empiris Kantor Cabang Bank Pemerintah dan Swasta Di Kota Padang).

Ikatan Akuntansi Indonesia. 2001. Standar Profesiona Akuntansi Publik. Salemba Empat. Jakarta

Undang-Undang Nomor 23 Tahun 2004 Tentang Pemerintah Daerah

Peraturan Pemerintah Nomor 18 Tahun 2016 Tentang Perangkat Daerah

Peraturan Pemerintah Nomor 41 Tahun 2007 Tentang Organisasi Perangkat Daerah

Badewin, Efektivitas Pengendalian Internal, Asimetri Informasi Dan Implementasi GGG Terhadap Kecenderungan Kecurangan Akuntansi Pada Organisasi Perangkat Daerah Kab. Indragiri Hilir 